\title{
Nytt om navn
}

\section{Forskningspris til Stein Ørn}

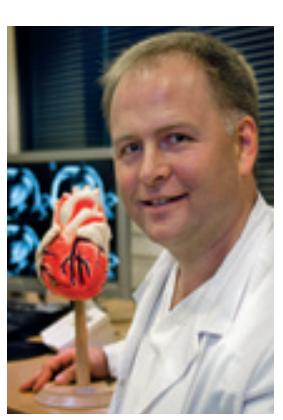

Stein Ørn. Foto Svein $G$ Lunde, Stavanger universitetssjukehus
Stein Ørn (f. 1968)

ved Stavanger universitetssjukehus er tildelt sykehusets forskningspris for 2010. Komiteen ga følgende begrunnelse for tildelingen: «Stein Ørn disputerte i september 2009 med avhandlingen Myocardial infarction: healing, scar size and left ventricular remodelling. I sin avhandling har Ørn arbeidet med deteksjon av mikrovaskulær obstruksjon med kontrast MRI hos pasienter med hjerteinfarkt behandlet med percutan coronar intervensjon (PCI). I arbeidet viser Ørn at grad av mikrovaskulær obstruksjon er relatert til infarktstørrelse og remodellering av venstre ventrikkel. Han har i tillegg vist at det er sammenheng mellom grad av mikro- vaskulær obstruksjon og inflammasjonsmarkører etter hjerteinfarkt. Disse funnene har klinisk betydning både for invasiv og noninvasiv kardiologisk behandling av pasienter med infarkt.

Stein Ørns arbeid blir av kollegaer betegnet som viktig forskning når det gjelder forståelsen av remodellering av venstre ventrikkel etter gjennomgått infarkt. Komiteen legger vekt på at dette er forskningsarbeid av høy internasjonal kvalitet og betydning. Arbeidet har mottatt internasjonal oppmerksomhet og er publisert $\mathrm{i}$ anerkjente tidsskrifter.

Komiteen tillegger også vekt at arbeidet til Stein Ørn har hatt vesentlig betydning for utviklingen av kardial MRI ved SUS. Dette har lagt grunnlaget for flere nyere og pågående studier ved kardiologisk seksjon. Et eksempel på dette er studier knyttet til stamcelle terapi etter hjerteinfarkt.

Stein Ørn har også deltatt i og deltar i en rekke andre studier, og er en flittig benyttet foreleser i inn og utland. Han har skrevet lærebokkapitler, vært redaktør for lærebok i sykdomslære og redaksjonsmedlem $i$ internasjonale tidsskrift.

Med sitt arbeid er Stein Ørn en av de som sterkt profilerer Stavanger Universitetssjukehus som et universitetssykehus. Stein Ørn er også et kjent navn i sykkelmiljøet i Stavanger.»

\section{Kåss utnevnt til statssekretær for helseministeren}

Robin Martin Kåss (f. 1977) er utnevnt som statssekretær for helse- og omsorgsminister Anne-Grete Strøm-Erichsen. Han har vært statssekretær i Olje- og energidepartementet siden 2008.

Kåss er utdannet lege. Han var leder for Porsgrunn Arbeiderparti i årene 2007-10 og har sittet i bystyret i Porsgrunn i to perioder.

Han var tidligere fastlege ved Solum Legesenter og har vært medisinskfaglig ansvarlig for Skien legevakt og for voldtektsmottaket i Telemark.

\section{Doktoravhandlinger}

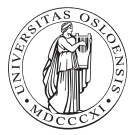

Universitetet i Oslo http://www.med.uio.no/disputaser/

Line Mari Flornes, ph.d. The antigen presenting cell lectin-like receptor gene complex, APLEC, regulates susceptibility to oil induced arthritis. Utgår fra Institutt for medisinske basalfag. Disputas 13.8. 2010.

Bedømmelseskomité: Rikard Holmdahl, Karolinska Institutet, Stockholm, ShuoWang Qiao, Institutt for klinisk medisin, Universitetet i Oslo, og Gustav Gaudernack, Institutt for klinisk medisin, Universitetet i Oslo.

Veiledere: Sigbjørn Fossum, Erik Dissen og Michael Daws.

Harald Lenz, ph.d. Can postoperative analgesia be improved by the choice and timing of analgesics? Utgår fra Institutt for sykehusmedisin, Oslo universitetssykehus, Ullevål. Disputas 19.8. 2010.

Bedømmelseskomité: Eija Kalso, Pain Clinic, Helsinki University Central Hospital, Finland, Petter C. Borchgrevink, Institutt for sirkulasjon og bildediagnostikk, Norges teknisk-naturvitenskapelige universitet, og Anne Cathrine Staff, Institutt for klinisk medisin, Universitetet i Oslo.
Veiledere: Johan Ræder og Audun Stubhaug.

Oskar H. Sommer, ph.d. Agitation in patients with dementia - challenges in diagnosis and treatment. Utgår fra Institutt for klinisk medisin, Oslo universitetssykehus, Ullevål. Disputas 20.8. 2010.

Bedømmelseskomité: Dag Årsland, Institutt for klinisk medisin, Universitetet i Oslo, Elisabet Londos, Neuropsykiatriske kliniken, Skånes universitetssjukhus, Malmö, Sverige, og Leif Gjerstad, Institutt for klinisk medisin, Universitetet i Oslo.

Veileder: Knut Enegdal.

Ingrid Eitzen, ph.d. Knee function and rehabilitation after anterior cruciate ligament injury. Early functional assessments and interventions. Utgår fra Ortopedisk avdeling, Oslo universitetssykehus, Ullevål. Disputas 25.8. 2010.

Bedømmelseskomité: G. Kelley Fitzgerald, Translational Research Center, University of Pittsburgh, PA, USA, Suzanne Werner, Stockholm Sports Trauma Research Center, Karolinska Institutet, Stockholm, og Jan Erik Madsen, Institutt for klinisk medisin, Universitetet i Oslo.

Veiledere: May Arna Risberg, Lars Engebretsen og Lynn Snyder-Mackler.
Johanna Hol, ph.d. Sorting, storage and secretion of neutrophil-recruiting $C X C$ chemokines from endothelial cells. Utgår fra Institutt for patologi. Disputas 27.8. 2010.

Bedømmelseskomité: Daniel Cutler, Medical Research Council Lab. for Molecular Cell Biology, UCL, London, England, Marit Inngjerdingen, Immunologisk institutt, Oslo universitetssykehus, og Svein Olav Kolset, Institutt for medisinske basalfag, Universitetet i Oslo.

Veiledere: Guttorm Haraldsen og Helge Scott.

Solomon Abebe Yimer, ph.d. Millennium development goal six and the lost indicator for case detection in tuberculosis control: investigating diagnostic delay and the infectious pool in Ethiopia. Utgår fra Institutt for helse og samfunn, Internasjonal helse. Disputas 27.8. 2010.

Bedømmelseskomité: Anthony David Harries, International Union against Tuberculosis and Lung Disease, Storbritannia, Tehmina Mustafa, Universitetet i Bergen, og Christoph Gradmann, Institutt for helse og samfunn, Universitetet i Oslo.

Veileder: Gunnar Bjune. 